\title{
Elevation influence the macrofungi diversity and composition of Gunung Korbu, Perak, Malaysia
}

\author{
M.B. NUR 'AQILAH' ${ }^{1, \bullet}$, S. NURJANNAH' ${ }^{2}$, S. SALLEH ${ }^{2}$, B.K. THI ${ }^{2}$, Z. AHMAD FITRI', \\ M. MOHD KHAIRUL FAIZI ${ }^{1}$, K.M. HAJA MAIDEEN ${ }^{1}$, M.S. NIZAM ${ }^{1}$ \\ ${ }^{1}$ Faculty of Science and Technology, Universiti Kebangsaan Malaysia. 43600 Bangi, Selangor Darul Ehsan, Malaysia. `email: nuraqilah@ukm.edu.my \\ ${ }^{2}$ Mycology and Pathology Branch, Forest Health and Conservation Programme, Forest Biodiversity Division, Forest Research Institute Malaysia. 52109 \\ Kepong, Selangor Darul Ehsan, Malaysia
}

Manuscript received: 13 January 2020. Revision accepted: 29 March 2020.

\begin{abstract}
Nur 'Aqilah MB, NurJannah S, Salleh S, Thi BK, Ahmad Fitri Z, Mohd Khairul Faizi M, Haja Maideen KM, Nizam MS. 2020. Title. Biodiversitas 21: 1707-1713. Fructification of macrofungi depends on two main factors, abiotic and biotic. In this study, the main focus is to determine the macrofungi composition and diversity as the effect of elevation and substrate. Macrofungi collection was conducted at three different elevations along the trails (Trail A, B, and C) of Gunung Korbu in July 2019. The sampling area was divided by ascent elevation from the Seroja Camp to the Rimba Gate (Trail A, $796 \mathrm{~m}$ above sea level[a.s.1]), the Seroja Camp to the Kijang Camp (Trail B, $1092 \mathrm{~m}$ a.s.l) and the Kijang Camp to the summit of Gunung Korbu (Trail C, $2183 \mathrm{~m}$ a.s.1). The collected macrofungi were photographed, described based on their macroscopic characters and any colour changes when bruising or chemicals reactions were recorded. In total 90 macrofungi specimens were in good condition belonging to 6 families from 13 genera, including the unidentified. About $93.33 \%$ (84 specimens) of the collections are saprotrophic fungi and six parasitic fungi. Trail B recorded the highest diversity index of 2.20 and 0.87 for Shannon Index and Simpson index, respectively. Non-metric multidimensional scaling ordinations showed a clear separation pattern of macrofungi community found in three different trails, with most of the specimens found in Trail B.
\end{abstract}

Keywords: Distinctive features, diversity, Gunung Korbu, macrofungi

\section{INTRODUCTION}

Macrofungi are known as macromycetes or larger fungi due to its visible fruiting bodies (sporocarps). The bestknown examples of macrofungi are the mushrooms, puffballs, bracket fungi, and toadstools. Macrofungi are categorised under the phylum Basidiomycota and a few members under Ascomycota. The tropical region undoubtedly hosts vast biodiversity. To date, more than 93\% of fungal species in the world are still unknown (Cannon et al. 2018) and in Malaysia particularly, reported about $70-80 \%$ of fungal species have yet to be discovered (Corner 1996; Lee et al. 1995). Interestingly, new species are still being identified in the tropics (Douanla-Meli et al. 2007) thus, documenting tropical macrofungi diversity is crucial to compile the information. One of the alternatives ways of documenting macrofungi diversity is via foray activities. The main objectives of a foray activity varies, for economic (e.g, food, medicinal) (Tibuhwa 2013), and education purposes (i.e. scientific study) (Donatha 2013). In Peninsular Malaysia, foray is limited where the local are hunting on selected edible macrofungi species (Chang and Lee 2004) which easily found in rubber plantation or gelam (Melaleuca cajuputi) forest. However, foray in generally have not been adopted as one of Malaysia culture and this is may due to the limited and scares reports in publications (Chang and Lee 2004) on edible macrofungi and taxonomic experts (Hyde 2003) in identification.
Furthermore, infrequent collection of macrofungi due to the growths pattern and their distribution are depends on several environmental factors. Among the factors, seasonality and year to year annual variation including precipitation and temperature are often show significance influence the macrofungi diversity (Lodge et al. 2004; Lee et al. 2002). For example, in Assam, India, the most collection of macrofungi is made during summer (18 species) followed by autumn (13 species), rainy season (9 species), spring (8 species) and winter (5 species) (Parveen et al. 2017). Natural castospshore in Tropical Pacific region for instance, Malaysia, faced monsoon season, where the macrofungi species grow abundantly (Zainuddin et al. 2010) compared during the El Nino strikes, the chances to find macrofungi is lesser than usual. Besides, the degree of succession can be viewed in several perspectives such as succession of sporocarps production, and changes occur in the vegetation which indirectly alter the quality of the substratum are among the major contributor in shaping the macrofungi community composition (Lodge et al. 2004). In term of succession of sporocarps production on leaf litter, after certain species of Marasimus decomposed leaf litter, some Lepiota species able to grow (Hedger 1985).

Malaysian forest classification was based on abiotic and biotic factors (Symington 1943; Wyatt-Smith 1964; Fox 1978). Forests are classified as lowland and hill dipterocarp forest with an elevation below $1200 \mathrm{~m}$, while at 1200 to $1500 \mathrm{~m}$, lower montane forests dominate. At $1800 \mathrm{~m}$ above sea level, the forest is known as upper montane forest and 
mossy forest. Subalpine and alpine forests can be found at $2900 \mathrm{~m}$ and $3500 \mathrm{~m}$, respectively (Chan et al. 2019). Studies on the diversity of macrofungi in Malaysia in the highlands/ mountains were also recorded but not as often as those conducted in the lowlands. For example, in East Malaysia, Sarawak about 54 polypore fungal genera were collected from Lambir Hills National Park (Salleh et al. 2016). Besides, diversity of macrofungi was also reported from Gunung Singai (Moi 2012) and Gunung Murud (Sepiah and Norhayati 2009), most of the macrofungi reported were belongs to poroid, agarics, and non-agarics. Meanwhile, in Peninsular Malaysia, the previous studies on mountain macrofungi were first reported by Chip (1921; as reported by Lee et al. 2012). In the Northern region of Peninsular Malaysia, especially Kedah, the microflora of four mountains have been explored (Kuthubutheen 1981; Noorlidah et al. 2005) while in the southern region, Gunung Angsi (Negeri Sembilan), Gunung Ophir (Melaka), Gunung Ledang (Johor) (Thi and Lee 2017), Gunung Panti (Johor), Gunung Lambak (Johor), and Gunung Pulai (Johor) are among the mountains where the inventories of macrofungi were conducted (as reported by Lee et al. 2012). Additionally, the Titiwangsa Range in Pahang has several collections of macrofungi covering various types of mountain vegetation from hill to montane forests documented from Cameron Highlands (Thi and Lee 2011) and Fraser's Hills (Thi and Lee 2010a; Thi et al. 2011; Thi et al. in press); hill dipterocarps forest (Gunung Tahan), and limestone forests (Gunung Senyum (Thi and Lau 2012); Gunung Jebak Puyuh). It also reported new fungi records or new species might be found in the mountain area. For instant, five new species from mountain Oseo in Korea were recorded (Lee et al. 2014).

The state of Perak has about twenty mountains, and the highest mountain is Gunung Korbu, $2182 \mathrm{~m}$ a.s.l. located in the Hulu Kinta Forest Reserve and reported as the second highest mountain in Peninsular Malaysia behind Gunung Tahan in Pahang. The vegetation of this mountains comprises of dipterocarp forests, upper dipterocarp forests, montane forests, and ericaceous forests (Chan et al. 2019). Strategically located within the Kinta Valley Geopark, Gunung Korbu is part of prerequisite site for biodiversity and geological heritage. In Perak, fungal biodiversity has been reported at Gunung Batu Putih (Chip 1921 as reported by Lee et al. 2012), but to date, fungal biodiversity has not been studied at Gunung Korbu. Thus, Gunung Korbu has been selected as the site to study the diversity of macrofungi in the mountain areas, and this study aimed to provide a list of macrofungi diversity in Gunung Korbu. The preliminary findings on the macrofungi collected from Gunung Korbu are presented in this paper.

\section{MATERIALS AND METHODS}

\section{Study site}

A study of the macrofungi diversity had been carried out at Gunung Korbu ( $\left.4^{\circ} 41^{\prime} \mathrm{N} 101^{\circ} 18^{\prime} \mathrm{E}\right)$ during the
Gunung Korbu Scientific Expedition on $1^{\text {st }}$ July to 4th July 2019 organized by Department of Mineral and Geoscience Malaysia, Perak (Jabatan Mineral dan Geosains Malaysia, Perak, JMG Perak) in collaboration with many research institutes. During the four-day expedition, no rainfall was recorded, and the sampling areas were relatively limited as sampling was only possible along the climbing trails due to the geographic conditions of Gunung Korbu. Samples were collected along the hiking trails, which are divided into three main sections; Trail A, Seroja Camp (796 m above sea level [a.s.1]; $\left.04^{\circ} 40.482^{\prime} \mathrm{N}, 101^{\circ} 16.788^{\prime} \mathrm{E}\right)$, Trail B, Kijang Camp (1092 m a.s.1; 04 $\left.39.415^{\prime} \mathrm{N}, 101^{\circ} 16.333^{\prime} \mathrm{E}\right)$, and lastly the Trail C, Gunung Korbu (2183 m a.s.1, 04 ${ }^{\circ}$ $41^{\prime} \mathrm{N}, 101^{\circ} 18^{\prime} \mathrm{E}$ (Figure 1).

\section{Procedures}

For the macrofungal collection, the samples were cautiously removed from the substrate with a sharp knife or soil shovel to avoid leaving any residue on the specimens/ mushrooms. To avoid any damage to the fruit bodies and to prevent specimens from dehydrating, small and mediumsized macrofungi were stored in plastic containers while large-sized specimens were wrapped using aluminum foils. The fruit bodies were photographed and information such as altitude, habitat, and substrate was recorded in the field. Macroscopic characteristics for example color, shape, size of the stipe, cap, gills, and odor were examined, described and recorded. Spore prints were prepared to determine the spore color and used in microscopic examination for identification and classification of macrofungi. Chemical reactions e.g. potassium hydroxide $(\mathrm{KOH})$ was also used to observe and record any color change on macrofungi (Lodge et al. 2004). The macrofungi samples were then dried in an oven at $40^{\circ} \mathrm{C}$ before deposited as herbarium specimens at National University of Malaysia (Universiti Kebangsaan Malaysia, (UKMB)). Microscopic characteristics, for example, the shapes, size and ornamental of the spores, basidium, hyphae, cystidia were observed under microscope. The identification of macrofungi was based on macroscopic and microscopic characteristics using appropriate keys. A recent nomenclature of macrofungi was checked at the Index Fungorum (http: //www.indexfungorum.org).

\section{Data analysis}

To determine the diversity within a community, the species richness and evenness were calculated according to the Shannon Diversity Index (H') and Simpson's Index (D). The analysis was conducted using macrofungi species composition and performed using Paleontological Statistics (PAST) version 2.17c (Hammer et al. 2001). To visualize and compare the composition of species community between three trails, a non-metric multidimensional scaling (NMDS) ordination of Bray-Curtis similarity matrices were drawn using PRIMER v6.1.9 (Primer-E Ltd, Plymouth, UK) with PERMANOVA+ v1 (Clarke and Gorley 2006). 

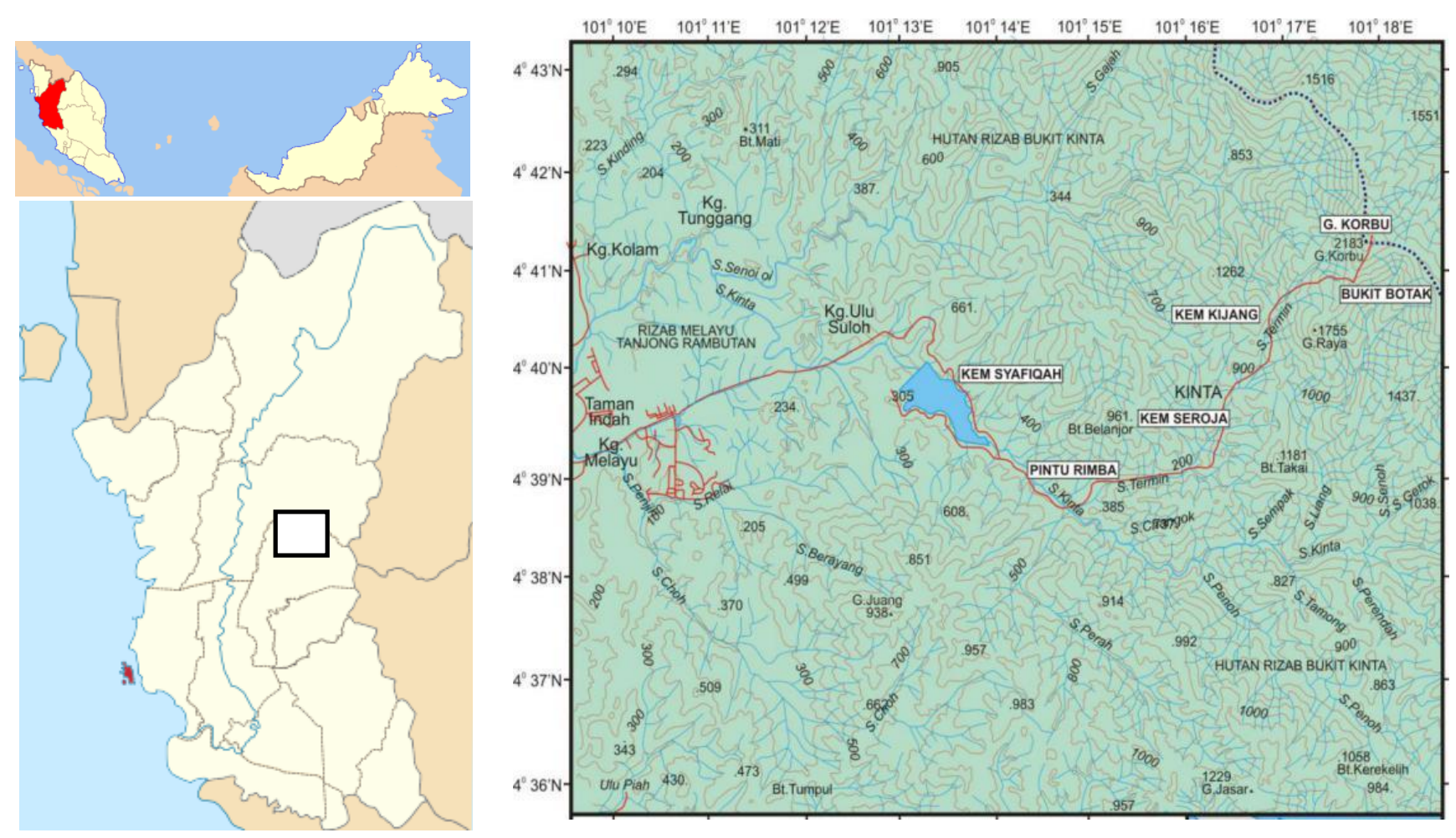

Figure 1. Location of the study area in Gunung Korbu, Perak, Malaysia. Source: RS/GIS Laboratory, SSDES, Geography Department, FSSK, UKM

\section{RESULTS AND DISCUSSION}

\section{Collections}

From this study, the collected macrofungi were listed in Table S1. From a total of 107 samples, 90 samples were in intact conditions, whereas 17 other samples were damaged/rotten possibly due to the weather condition; or eaten by an insect (Table S1). Macrofungi specimens with good conditions that identified up to the family level were included in the analysis. From 90 macrofungi specimens, only 6 families from 13 genera, including the unidentified, were identified (Table 1). In this study, the most enumerated macrofungi belong to Basidiomycota. Among the collections, member of family Polyporaceae was recorded the highest number of specimens (63 specimens) consisted of Polyporus, Microsporus, Favolus, Microporus, Lenzites, Trametes, and unidentified. The species of Microporus (31 specimens) were frequently recorded during this collecting trip.

\section{Macrofungal species richness and diversity}

Common diversity index, Shannon diversity index, and Simpson's diversity index were employed to analyze the samples. Shannon index showed a high diversity on Trail B with a value of 2.20 . This value indicates that the study area at Gunung Korbu has a high diversity of species because the Shannon Diversity Index $\left(\mathrm{H}^{\prime}\right)$ falls between
1.5-3.5. Meanwhile, the Shannon Similarity Index (E') value range between $0-1$ that showed the value of 1 represents uniformed species within the area. The three trails of Gunung Korbu showed highly-uniformed species, especially in Trail $C\left(E^{\prime}=1.0\right)$, followed by Trail A $\left(E^{\prime}=\right.$ $0.88)$, and Trail $\mathrm{B}\left(\mathrm{E}^{\prime}=0.82\right)$. This observation is due to only one macrofungi specimens belonging to Stereaceae enumerated at Trail C.

Ecologically, most terrestrial macrofungi can be classified into three feeding modes: saprophytes, parasites, and the symbiotic (ectomycorrhizal, ECM) species. Macrofungi fruiting on woody substrate is usually either saprobes or plant pathogens (Mueller et al. 2007). In this study, two feeding modes were encountered, i.e. saprophytic and parasitic, with the majority of the macrofungi specimens being classified as saprophytic fungi (93.33\%) under Basidiomycota. There are a few unidentified species belonging to Ganodermataceae and Polyporaceae are considered as parasitic groups. Most of the specimens are found on decayed wood $(36 \%)$ followed by living tree $(32 \%)$. The family Polyporaceae, which recorded the highest number of species found in this study, recorded 6 species found on decayed trees followed by 6 species found on living trees and 4 species were also found on the twigs. The abundance of Polyporaceae in an area is due to the availability of substrates; such as decayed wood, living trees, and twigs for them to grow. 
Table 1. Tabulation of macrofungal taxa in Gunung Korbu, Perak, Malaysia

\begin{tabular}{|c|c|c|c|c|c|}
\hline \multirow{2}{*}{ Phylum } & \multirow{2}{*}{ Family } & \multirow{2}{*}{ Genus } & \multicolumn{3}{|c|}{ Number of individuals } \\
\hline & & & Trail_A & Trail_B & Trail_C \\
\hline \multirow[t]{2}{*}{ Basidiomycota } & Ganodermataceae & Amauroderma & 0 & 2 & 0 \\
\hline & & Ganoderma & 0 & 4 & 0 \\
\hline \multirow[t]{2}{*}{ Basidiomycota } & Hymenochaetaceae & Phellinus & 0 & 4 & 0 \\
\hline & & Indet. & 0 & 8 & 0 \\
\hline Basidiomycota & Meruliaceae & Cymatoderma & 0 & 3 & 0 \\
\hline Basidiomycota & Mycenaceae & Indet. & 3 & 0 & 0 \\
\hline \multirow[t]{6}{*}{ Basidiomycota } & Polyporaceae & Favolus & 0 & 4 & 0 \\
\hline & & Lenzites & 5 & 0 & 0 \\
\hline & & Microporus & 15 & 16 & 0 \\
\hline & & Polyporus & 0 & 4 & 0 \\
\hline & & Trametes & 4 & 0 & 0 \\
\hline & & Indet. & 3 & 12 & 0 \\
\hline Basidiomycota & Stereaceae & Stereum & 2 & 0 & 1 \\
\hline
\end{tabular}

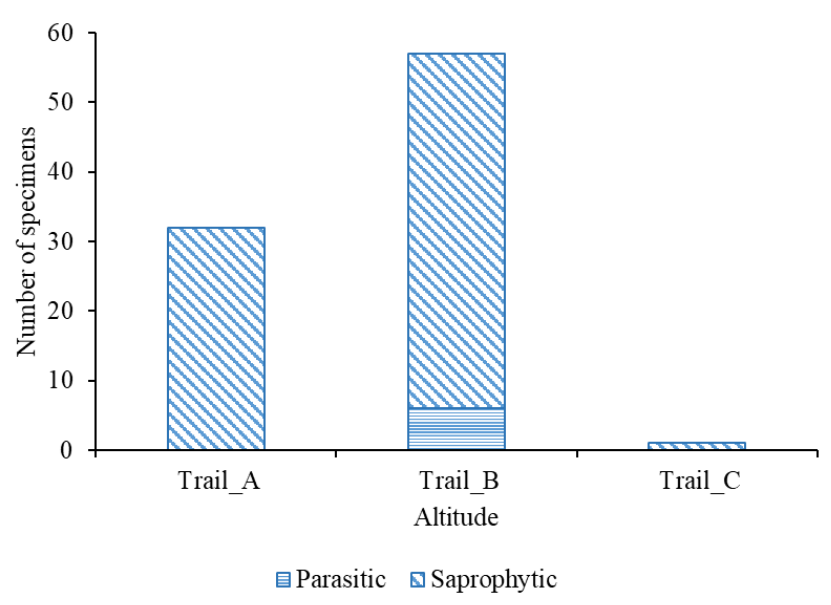

Figure 2. Number of specimens representing feeding mode of macrofungi in three different trails

Based on Figure 3, the non-metric multidimensional scaling (NMDS) ordinations of the macrofungi community at three different trails with different altitudes show a clear pattern of distribution macrofungi community. Trail A located between 300- $799 \mathrm{~m}$ above sea level recorded 32 specimens comprising of families Polyporaceae, Mycenaceae and Stereaceae. Sampling along the trail A also recorded the highest number of specimens from the family Polyporaceae with 27 specimens. Meanwhile, trail B with an altitude of between $800-1200 \mathrm{~m}$ from sea level reported the highest number of specimens (57 specimens) consisting of families Hymenochaetaceae, Polyporaceae, Meruliaceae, and Ganodermataceae. The Polyporaceae recorded the highest number of specimens found throughout the B specimen of 36 specimens followed by Hymenochaetaceae (12 specimens), Ganodermataceae (6 specimens) and Meruliaceae (3 specimens). Trail C situated above $1040 \mathrm{~m}$ from sea level showed the lowest number of specimens, of which only one species was identified from the Stereaceae family, which is the species of Stereum ostrea.
Table 2. Diversity indices of macrofungi communities collected in three different trails at Gunung Korbu, Perak, Malaysia

\begin{tabular}{lccc}
\hline Index/Value & Trail_A & Trail_B & Trail_C \\
\hline Simpson_1-D & 0.82 & 0.87 & 0 \\
Shannon_H & 1.82 & 2.20 & 0 \\
Evenness_e`H/S & 0.88 & 0.82 & 1 \\
\hline
\end{tabular}

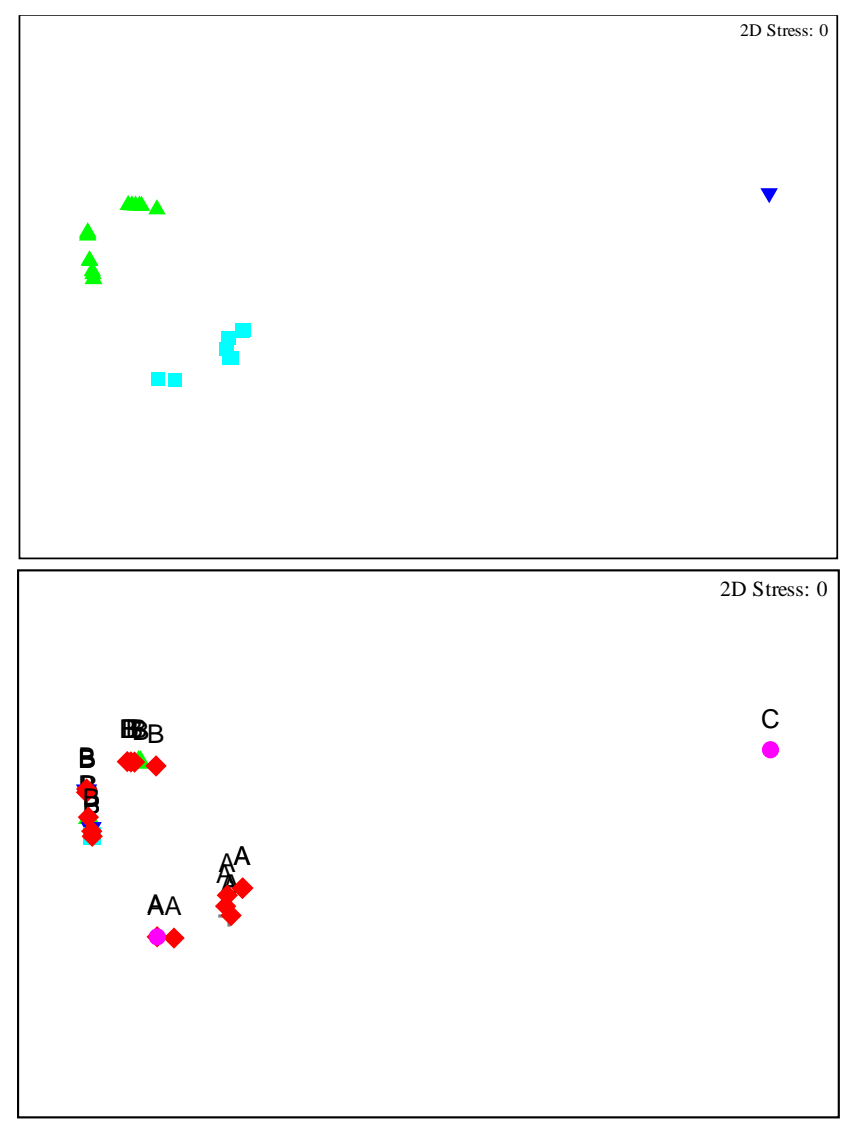

Figure 3. Non-metric multidimensional scaling (NMDS) ordinations of macrofungi community structure displaying variations among (top) trails and (bottom) family of macrofungi. Square, Trail A; Upper triangle, Trail B; Inverse triangle, Trail C. Macrofungi Family: Upper triangle, Ganodermataceae; Inverse triangle, Hymenochaetaceae; Square, Meruliaceae; Diamond, Polyporaceae; Circle, Stereaceae; Crosses, Mycenaceae 
Table S1. List of macrofungi collection in Gunung Korbu, Perak, Malaysia

\begin{tabular}{|c|c|c|c|c|c|c|c|}
\hline Family & Genus & Spesies & Collection & $\begin{array}{l}\text { Sample } \\
\text { condition }\end{array}$ & Trail & $\begin{array}{l}\text { Altitude } \\
\text { (m. a.s.l.) }\end{array}$ & $\begin{array}{l}\text { Feeding } \\
\text { mode }\end{array}$ \\
\hline Auriculariaceae & Auricularia & Auricularia delicata & 0 & Poor condition & B & 800 & Saprophyte \\
\hline Entolomataceae & Entoloma & Entoloma sp. & 0 & Poor condition & $\mathrm{C}$ & 1040 & Saprophyte \\
\hline Ganodermataceae & Amauroderma & Amauroderma sp. & 2 & Good condition & $\mathrm{B}$ & 802 & Parasite \\
\hline Ganodermataceae & Ganoderma & Ganoderma sp. & 2 & Good condition & B & 800 & Parasite \\
\hline Ganodermataceae & Ganoderma & Ganoderma sp. & 2 & Good condition & B & 819 & Saprophyte \\
\hline Hymenochaetaceae & Phellinus & Phellinus/Inonotus & 4 & Good condition & B & 799 & Saprophyte \\
\hline Meruliaceae & Cymatoderma & Cymatoderma sp. & 3 & Good condition & $\mathrm{B}$ & 800 & Saprophyte \\
\hline Mycenaceae & Unknown & Unknown & 3 & Good condition & A & 400 & Saprophyte \\
\hline Physalacriaceae & Oudemansiella & Oudemansiella sp. & 0 & Poor condition & B & 799 & Saprophyte \\
\hline Polyporaceae & Favolus & Favolus tenuiculus & 2 & Good condition & $\mathrm{B}$ & 800 & Saprophyte \\
\hline Polyporaceae & Favolus & Favolus sp. & 0 & Poor condition & $\mathrm{B}$ & 800 & Saprophyte \\
\hline Polyporaceae & Favolus & Favolus grammocephalus & 2 & Good condition & B & 860 & Saprophyte \\
\hline Polyporaceae & Lentinus & Lentinus sp. & 0 & Poor condition & A & 350 & Saprophyte \\
\hline Polyporaceae & Lenzites & Lenzites sp. & 2 & Good condition & A & 550 & Saprophyte \\
\hline Polyporaceae & Lenzites & Lenzites sp. & 3 & Good condition & A & 580 & Saprophyte \\
\hline Polyporaceae & Microporus & Microporus affinis & 5 & Good condition & A & 400 & Saprophyte \\
\hline Polyporaceae & Microporus & Microporus affinis & 5 & Good condition & A & 480 & Saprophyte \\
\hline Polyporaceae & Microporus & Microporus vernicipes & 5 & Good condition & A & 500 & Saprophyte \\
\hline Polyporaceae & Microporus & Microporus affinis & 6 & Good condition & $\mathrm{B}$ & 799 & Saprophyte \\
\hline Polyporaceae & Microporus & Microporus xanthopus & 5 & Good condition & $\mathrm{B}$ & 800 & Saprophyte \\
\hline Polyporaceae & Microporus & Microporus affinis & 5 & Good condition & $\mathrm{B}$ & 819 & Saprophyte \\
\hline Polyporaceae & Polyporus & Polyporus sp. & 4 & Good condition & $\mathrm{B}$ & 799 & Saprophyte \\
\hline Polyporaceae & Trametes & Trametes menziesii & 4 & Good condition & A & 400 & Saprophyte \\
\hline Polyporaceae & Unknown & Unknown & 3 & Good condition & A & 400 & Saprophyte \\
\hline Polyporaceae & Unknown & Unknown & 5 & Good condition & $\mathrm{B}$ & 799 & Saprophyte \\
\hline Polyporaceae & Unknown & Unknown & 2 & Good condition & B & 804 & Parasite \\
\hline Polyporaceae & Unknown & Unknown & 5 & Good condition & $\mathrm{B}$ & 819 & Saprophyte \\
\hline Polyporaceae & Unknown & Unknown & 0 & Poor condition & B & 890 & Saprophyte \\
\hline Stereaceae & Stereum & Stereum ostrea & 1 & Good condition & $\mathrm{C}$ & 1030 & Saprophyte \\
\hline Unknown & Unknown & Unknown & 5 & Good condition & $\mathrm{A}$ & 350 & Saprophyte \\
\hline Unknown & Unknown & Unknown & 2 & Good condition & A & 450 & Saprophyte \\
\hline Unknown & Unknown & Unknown & 4 & Good condition & $\mathrm{B}$ & 840 & Saprophyte \\
\hline Unknown & Unknown & Unknown & 1 & Good condition & $\mathrm{C}$ & 1008 & Saprophyte \\
\hline Unknown & Unknown & Unknown & 5 & Good condition & $\mathrm{C}$ & 1040 & Saprophyte \\
\hline Xylariaceae & Xylaria & Xylaria polymorpha & 0 & Poor condition & $\mathrm{B}$ & 804 & Saprophyte \\
\hline
\end{tabular}

\section{Discussions}

Mycoflora of Malaysia reported two major phyla, Ascomycota and Basidiomycota consisting of 1141 species and 1820 species, respectively (Lee et al. 2012). The total number of specimens and taxa found in this study was relatively lower compared to other similar studies (Thi and Lau 2012; Sepiah and Norhayati 2009). The number of factors that contributed to this low number of macrofungi taxa and one of the factors is vegetation type. The composition and diversity of macrofungi were different may due to the difference in vegetation types along with the altitude (Moore 2008) which leads to the availability of substrates (Lodge et al. 2004; Ujang and Jones 2001). At the higher altitude, most of the vegetation was dominates by mosses, liverworts, and lichens (Moore 2008). Andrew et al. (2013) state the diversity of macrofungi is higher in areas with low and medium altitudes compared to those with high altitudes. From this study, at altitudes of above
$1040 \mathrm{~m}$, no samples were obtained. This finding also congruent with Sepiah and Norhayati (2009) study at Gunung Murud, Sarawak, where $73.31 \%$ of the collections and more diverse fungi taxa were found at an altitude below $1800 \mathrm{~m}$ above sea level. Some of the macrofungi species especially ectomycorrhizas (ECM) are host-specific (Moore et al. 2011; Roy et al. 2013; Essene et al. 2017) which associated with only $2 \%$ of woody plant (Brundrett and Tedersoo 2018). There are reports that showed ECM are highly diverse in temperate forest compared to tropical forest (Tedersoo et al. 2012; Kennedy et al. 2012) due to the temperate forest was often dominated by the ECM host such as Alnus (Roy et al. 2013), Pinus (Cullings et al. 2000) and Quercus (Morris et al. 2009). In this study, there is absence of ECM and this may due to lack of host, mainly Dipterocarpaceae and the soil properties which had a positive significant influence ECMs species richness and diversity (Luo et al. 2016). 
According to Schmit et al. (2005) and Lodge et al. (2004) claimed that higher plant diversity and density generates higher diversity of substrate for macrofungi, which may, in turn, lead to higher macrofungi diversity because of the plant vigilante as habitat and source of energy for most macrofungi especially for poroid fungi. In Malaysia, Polyporaceae is the largest and most common family with 42 genera and 327 species and frequently found on a variety of substrates (Lee et al. 2012), mainly wood, available for them to grow on (Bolhassan et al. 2012). Moreover, most of the polypore fungi have tough and hard fruiting bodies that grow perennially and they can thus be found at almost any time of the year and abundantly in an area (Thi and Lee 2010b). These results correspond to the study by $\mathrm{Li}$ et al. (2018a) and Lee et al. (2014) where saprobic fungi, especially litter-decomposing macrofungi, are the dominant and diverse fungal group in tropical forests. Besides, according to Luo et al. (2016), no significant relationships were found between environment variables and the diversity and community composition of saprotrophic fungi in subalpine pine forest.

In higher altitude, the forest canopy gap was huge consequently prominent to higher light levels, higher temperatures and lower humidity drive to low sporocarp production (Jaya Seelan et al. 2014; Brown et al. 2006). In addition, the varied spore-producing structures which increase the degree of dispersal may contribute to the abundance of macrofungi species in an area (Aqilah et al. 2019; Raper et al. 1958). According to Li et al. (2018b) and Priyamvada et al. (2017), it is expected that more species can be recorded in different regions if the environment is optimum depending on the season, temperature and amount of rainfall. During the four days of collection on Gunung Korbu, no rainfall was recorded. Based on rainfall data from 2017 to 2019 obtained from the Malaysian Meteorological Department, it can be concluded that the rainfall from January to July in 2019 is significantly lower than in 2017 and 2018. The month of July 2019, where this study was conducted recorded only $72.2 \mathrm{~mm}$ of rain, which is extremely low compared to July 2018 (235.4 mm) and July 2017 (386.1 mm).

In conclusion, this is the first report on mycoflora of Gunung Korbu and further intensive studies (e.g, increase sampling period and effort) are required, as a new species or new record may be encountered in the area.

\section{ACKNOWLEDGEMENTS}

This study was supported by the UKM Research Grant [GGPM2019020].

\section{REFERENCES}

Andrew EE, Kinge TR, Tabi EM, Thiobal N, Mih AM. 2013. Diversity and distribution of macrofungi (mushrooms) in the Mount Cameroon Region. J Ecol Nat Environ 5 (10): 318-334

Aqilah M, Lee S.Y, Ayu Kalsum K. 2019. Macrofungi of Tasik Kenyir. In: Abdullah MT, Mohammad A, Nor Zalipah M, Safiih, Lola M (eds.). Greater Kenyir Landscapes. Springer, Cham.
Boddy L, Büntgen U, Egli S, Gange AC, Heegaard E, Kirk P, Mohammad $\mathrm{AB}$, Kauserud H. 2014. Climate variation effects on fungal fruiting. Fungal Ecol 10: 20-33.

Bolhassan MH, Abdullah N, Sabaratnam V, Tsutomu H, Abdullah S, Mohd N, Rashid N, Musa Y. 2012. Diversity and distribution of Polyporales in Peninsular Malaysia. Sains Malaysiana 41 (2): 155161.

Brown N, Bhagwat SA, Watkinson S. 2006. Macrofungal diversity in fragmented and disturbed forests of the Western Ghats of India. J Applied Ecol 43 (1): 11-17

Brundrett M, Tedersoo L. 2018. Evolutionary history of mycorrhizal symbioses and global host plant diversity. New Phytol 220 (4): 11081115 .

Cannon P, Hudson B.A, Aime M.C, Ainsworth A.M, Bidartondo M.A, Gaya E, Hawksworth D, Kirk P, Leitch IJ, Lucking R. 2018. State of the World's Fungi. Royal Botanic Gardens, Kew.

Chan KO, Muin MA, Anuar S, Andam J, Razak N, Aziz MA. 2019. First checklist on the amphibians and reptiles of Gunung Korbu, The Second Highest Peak in Peninsular Malaysia. Check List 15 (6): 1055-1069.

Chang YS, Lee SS. 2004. Utilisation of macrofungi species in Malaysia. Fungal Divers 15: 15-22.

Clarke KR, Gorley RN. 2006. Primer-E Ltd, Plymouth Routines in Multivariate Ecological Research software.

Corner EJH. 1996. The agaric genera Marasmius, Chaetocalathus, Crinipellis, Heimiomyces, Resupinatus, Xerula and Xerulina in Malesia. Beihefte Nova Hedwigia 111: 1-175

Cullings KW, Vogler DR, Parker VT, Finley SK. 2000. Ectomycorrhizal specificity patterns in a mixed Pinus contorta and Picea engelmannii Forest in Yellowstone National Park. Appl Environ Microbiol 66: 4988-4991.

Donatha DT. 2013. Wild mushroom- an underutilized healthy food resource and income generator: experience from Tanzania Rural Areas. J Ethnobiol Ethnomed 9: 49. DOI: 10.1186/1746-4269-9-49.

Douanla-Meli, C, Ryvarden L, Langer E. 2007. Studies of tropical African pore fungi (Basidiomycota, Aphyllophorales): Three new species from Cameroon. Beihefte Nova Hedwigia 84: 409-420.

Essene AL, Shek KL, Lewis JD, Peay KG, McGuire KL. 2017. Soil type has a stronger role than dipterocarp host species in shaping the ectomycorrhizal fungal community in a Bornean Lowland Tropical Rain Forest. Front Plant Sci 8: 1828.

Fox JED. 1978. Natural vegetation of Sabah, Malaysia. The physical environment and classification. J Trop Ecol 19 (2): 218-239.

Hammer O, Harper DAT, Ryan PD. 2001. PAST: Paleontological Statistics software package for education and data analysis. Palaeontologia Electronica 4 (1): 9.

Hedger J. 1985 Tropical agarics, resource relations and fruiting periodicity In: Moore D, Casselton LA, Wood DA, Frankland JC. (eds.). Developmental Biology of Higher Plants. Cambridge University Press, Cambridge.

Hyde KD. 2003. Mycology and its future in the Asia Region. Fungal Div 13: 59-68.

Jaya Seelan SS, Ahmad AH, Sepiah M, Tan PE. 2014. Biodiversity Inventory of macrofungi at Sungkai Wildlife Reserve, Perak, Malaysia. J Wildlife Parks 27: 17-24.

Kennedy PG, Matheny PB, Ryberg KM, Henkel TW, Uehling JK, Smith ME. 2012. Scaling up: examining the macroecology of ectomycorrhizal fungi. Mol Ecol 21: 4151-4154

Kuthubutheen AJ. 1981. Notes on the macrofungi of Langkawi. Malayan Nat J 34 (3): 123-130.

Lee SS, Alias SA, Jones EGB, Zainuddin N, Chan HT. 2012. Checklist of Fungi of Malaysia. Forest Research Institute Malaysia, Kepong.

Lee SS, Besl H, Salmiah U. 1995. Some fungi of the Sungai Halong and surrounding areas, Temenggor Forest Reserve, Hulu Perak, Malaysia. Malayan Nat J 48: 147-155.

Lee SS, Watling R, Sikin YN. 2002. Ectomycorrhizal basidiomata fruiting in lowland rain forests of Peninsular Malaysia. Bois et Forêts des Tropiques 274: 33-43.

Lee WD, Lee H, Fong JJ, Oh SY, Park MS, Quan Y, Jung PE, Lim YW. 2014. A checklist of the basidiomycetous macrofungi and a record of five new species from mt. Oseo in Korea. Mycobiology 42 (2): 132-9.

Li H, Guo J, Goldberg S, Sreekar R, Ye L, Luo X, Sysouphanthong P, Xu J, Hyde K, Mortimer P. 2018b. Fruiting patterns of macrofungi in tropical and temperate land use types in Yunnan Province, China. Acta Oecologica. 91. 7-15. 
Li H, Guo J, Samantha CK, Ye L, Xu J, Hyde KD, Mortimer PE. 2018a. Native forests have a higher diversity of macrofungi than comparable plantation forests in the Greater Mekong Subregion. Forests 9 (7): 402. DOI: $10.3390 / f 9070402$

Lodge DJ, Ammirati JF, O'Dell TE, Mueller GM. 2004. Collecting and Describing Macrofungi. Biodiversity of Fungi: Inventory and Monitoring Methods. Elsevier Academic Press, Amsterdam.

Luo X, Karunarathna SC, Luo YH, Xu K, Xu JC, Chamyuang S, Mortimer PE. 2016. Drivers of macrofungal composition and distribution in Yulong Snow Mountain, southwest China. Mycosphere 7 (6): 727-740

Moi LG 2012. Macrofungi from Gunung Singai, Sarawak, Malaysia. In Malaysia International Biological Symposium: Sustainable Management of Bioresources, 11th - 12th July 2012, Residence Hotel, Selangor, Malaysia.

Moore D, Robson GD, Trinci APJ. 2011. 21 ${ }^{\text {st }}$ Century Guidebook to Fungi. Cambridge University Press, Cambridge.

Moore PD. 2008 Ecosystem Series: Tropical Forest. Infobase Publishing, New York.

Morris MH, Perez-Perez MA, Smith ME, Bledsoe CS. 2009. Influence of host species on ectomycorrhizal communities associated with two cooccurring oaks (Quercus spp.) in a tropical cloud forest. FEMS Microbiol Ecol 69: 274-287.

Mueller GM, Schmit JP, Leacock PR, Buyck B. 2007. Global diversity and distribution of macrofungi. Biodiv Conserv 16 (1): 37-48.

Noorlidah A, Vikineswary S, Yusoff M, Desjardin DE. 2005. Higher Fungi of Northeast Langkawi. Malaysian J Sci 24: 95-102.

Parveen A, Khataniar L, Goswami G, Hazarika DJ, Das P, Gautom T, Barooah M, Boro RC. 2017. A study on the diversity and habitat specificity of macrofungi of Assam, India. Intl J Curr Microbiol Appl Sci 6 (12): 275-297.

Pegler DN. 1997. The larger fungi of Borneo. Natural History Publications, Kota Kinabalu, Malaysia.

Priyamvada H, Akila M, Singh RK, Ravikrishna R, Verma RS, Philip L, Marathe RR, Sahu LK, Sudheer KP, Gunthe SS. 2017. Terrestrial macrofungal diversity from the tropical dry evergreen biome of Southern India and its potential role in aerobiology. PLoS ONE 12 (1): e0169333. DOI: 10.1371/journal.pone.0169333.

Raper JR, Krongelb GS, Baxter MG. 1958. The number and distribution of incompatibility factors in Schizophyllum commune. Amer Nat 92 221-232.

Roy M, Rochet J, Manzi S, Jargeat P, Gryta H, Moreau PA, Gardes M 2013. What determines Alnus-associated ectomycorrhizal community diversity and specificity? a comparison of host and habitat effects at a regional scale. New Phytol 198: 1228-1238.

Salleh H, Ghani Y, Nelson S, Haryanie, Mohamad S, Yamashita S. 2016 Fungi in Sarawak: practical use of historical samples in the fungarium of the Forest Department Sarawak. Proceedings of the symposium "Frontier in tropical forest research: progress in joint projects between the Forest Department Sarawak and the Japan Research Consortium for Tropical Forests in Sarawak", 2016: 160-164

Schmit JP, Mueller GM, Leacock PR, Mata JL, Wu Q, Huang Y. 2005. Assessment of tree species richness as a surrogate for macrofungal species richness. Biol Conserv 121: 99-110
Sepiah M, Norhayati S. 2009. Macrofungi of Gunung Murud, Sarawak. In: UNIMAS Special Focus on Biodiversity Research Update 5 (2): 17.

Symington CF. 1943. Foresters' Manual of Dipterocarps. Malayan Forest Record No. 16. University of Malaya Press, Kuala Lumpur

Tedersoo L, Bahram M, Toots M, Diédhiou AG, Henkel TW, Kjøller R, Morris MH, Nara K, Nouhra E, Peay KG, Põlme S, Ryberg M, Smith ME, Kõljalg U. 2012. Towards global patterns in the diversity and community structure of ectomycorrhizal fungi. Mol Ecol 21: 41604170.

Thi BK, Lee SS. 2011. Macrofungal diversity of Cameron Highlands: A preliminary survey. In: Abd Rahman A R, Koh HL, Mohd Paiz K, Muhamad A, Latiff A. (eds.). Hutan Pergunungan Cameron Highlands: Pengurusan hutan, persekitaran fizikal dan kepelbagaian biologi. Siri Kepelbagaian Biologi Hutan 14. Jabatan Perhutanan Semenanjung Malaysia, Kepong.

Thi BK, Lau SS. 2012. Macrofungi of Gunung Senyum. Bulletin Supporting Plant and Animal Conservation in Malaysia, No. 15. Forest Research Institute Malaysia, Kepong.

Thi BK, Lee SS. 2010a. Macrofungi of Fraser's Hill: Part 1. Conservation Malaysia. Bulletin Supporting Plant and Animal Conservation in Malaysia, No. 11. Forest Research Institute Malaysia, Kepong.

Thi BK, Lee SS. 2010b. Some Macrofungi of Pulau Pangkor. Proceeding of Seminar Ekspedisi Saintifik Kepelbagaian Biologi Hutan Pulau Pangkor. Kertas 28: 1-7. Jabatan Perhutanan Semenanjung Malaysia, Kepong.

Thi BK, Lee SS. 2017. Diversity of macrofungi at Gunung Ledang Johor National Park. In Ahmad Naqiyuddin B, Abdul Rauf A, Farida Zuraina M.Y, Singh HR, Tokiman L (eds.) Gunung Ledang: Geology, Biodiversity and Socio-economic Environment. Penerbit Press Universiti Teknologi Mara, Shah Alam.

Thi BK, Lee SS, Zainuddin N, Chan HT. 2011. A Guidebook to the Macrofungi of Fraser's Hill. Forest Research Institute Malaysia, Kepong.

Tibuhwa DD. 2013. Wild Mushroom-An Underutilized Healthy Food Resource and Income Generator: Experience from Tanzania Rural Areas. J J Ethnobiol Ethnomed 9: 49. DOI: 10.1186/1746-4269-9-49.

Tsia MK. Aqilah M. 2019. Macrofungi of Pulau Bidong. Universiti Malaysia Terengganu J Undergrad Res 1 (2): 26-35

Ujang S, Jones EBG. 2001. Occurrence of wood inhabiting fungi in forests of Peninsular Malaysia. J Trop For Sci 13 (2): 237-245.

Whitmore TC. 1984. Tropical Rain Forests of the Far East. Clarendon Press, Oxford.

Wyatt-Smith J. 1964. A preliminary vegetation map of Malaysia with description of vegetation types. J Trop Geogr 18: 200-213.

Zainuddin N, Alias SA, Kin TB, See LS, Twu CH. 2010. Macrofungi of Pulau Redang, Terengganu and Pulau Aur, Johor in the South China Sea. J Sci Technol Tropics 6: 120-125.

Zhang Y, Zhou DQ, Zhao Q, Zhou TX, Hyde KD. 2010. Diversity and ecological distribution of macrofungi in the Laojun Mountain Region, Southwestern China. Biodiv Conserv 19: 3545-3563. 